\title{
STUDI PERBANDINGAN RANTAI PEMASARAN TANDAN BUAH SEGAR KELAPA SAWIT DI DESA JONGGON KABUPATEN KUTAI KARTANEGARA
}

\section{COMPARATIVE STUDY OF THE SUPPLY CHAIN FOR FRESH FRUIT BRUNCHES OF OIL PALM IN JONGGON VILLAGE KUTAI KARTANEGARA REGENCY}

\author{
Ahmad Reza Vahlevi¹, Ernita Obeth', Budi Winarni ${ }^{1}$ \\ ${ }_{1}^{1}$ Politeknik Pertanian Negeri Samarinda, Kampus Gunung Panjang, Jl. Samratulangi, Samarinda, \\ Indonesia \\ rezavahlevi@outlook.com
}

\begin{abstract}
This research is motivated by oil palm farmers, which is in contrast to the high demand for fresh fruit bunches, as the main raw material for producing crude palm oil. On the other hand, oil palm smallholders are also involved in several different supply chains. The purpose of this study was to determine the management of fresh fruit bunches marketing and the amount of profit received by farmers through the marketing of oil palm fresh fruit bunches in Jonggon Village, Kutai Kartanegara Regency. The analytical method used is descriptive quantitative and marketing margin analysis. The method of determining respondents used purposive sampling method and the respondents in this study were plasma and non-plasma farmers, collector traders and plasma cooperatives, and crude palm oil processing factories owned by PT. Niaga Mas Gemilang in Jonggon Village, Kutai Kartanegara Regency. The results of the respondents' research are in 2 running marketing channels, namely the first marketing channel, namely farmer-cooperative-processing factory, and the second one is farmertrader-processing factory. Farmers involved in the first supply chain get a profit of Rp. $900 / \mathrm{kg}$ and the farmers involved in the second supply chain get a profit of Rp. $1070 / \mathrm{kg}$.
\end{abstract}

Keywords: Marketers, Marketing Margins, Sales Profit, TBS Marketing Chain

\section{PENDAHULUAN}

Kelapa sawit merupakan tanaman penghasil minyak sawit dan inti sawit. Potensi hasil produksi crude palm oil (CPO) di Indonesia sangat besar apabila digunakan sebagai bahan baku produkproduk minyak, baik untuk dikonsumsi maupun tidak untuk dikonsumsi. Meningkatnya kebutuhan masyarakat mengakibatkan meningkatnya jumlah produksi kelapa sawit di Indonesia dari tahun ke tahun. Sejak tahun 1980, perkembangan produksi kelapa sawit dalam bentuk CPO di Indonesia terus mengalami peningkatan dengan rata-rata pertumbuhan sebesar $11,48 \%$ per tahun. Pada tahun 2018, neraca perdagangan Indonesia tercatat mengalami surplus sebesar 16,5 milyar USD untuk CPO dan turunannya dan sebesar 1,8 milyar USD untuk PKO dan turunannya. Hal ini menjadikan kelapa sawit sebagai komoditas penyumbang devisa terbesar di Indonesia (Dirjenbun, 2019).

Berbanding terbalik dengan tingginya permintaan Pemasaranan tandan buah segar (TBS) sebagai bahan untuk memproduksi CPO, keadaan ekonomi petani selalu berada dalam kondisi yang tidak menentu sebab harga TBS yang ditetapkan oleh pemerintah selalu fluktuatif yang menyebabkan petani kelapa sawit berada dalam kondisi yang dilematis untuk memenuhi kebutuhan keluarganya (Mukmin, 2014). Selain itu, menurut Asngari (2010), sudah menjadi ciri produk pertanian dimana produk petani pada saat panen dengan jumlah besar tetapi nilainya rendah karena harganya yang turun. Sebagai contoh, di Kabupaten Muara Enim pada tahun 2008 harga TBS sawit hanya Rp300/kg, dan di 
tahun 2010 harga TBS kelapa sawit naik menjadi sekitar Rp1.000/kg. Meskipun harga TBS tinggi akan tetapi taraf hidup petani skala kecil masih rendah. Hal ini yang membuat peneliti tertarik untuk melakukan penelitian dengan judul Analisis Rantai Pemasaran TBS Kelapa Sawit di Desa Jonggon Kabupaten Kutai Kartanegara.

Tujuan penelitian ini adalah untuk mengetahui bagaimana manajemen rantai pemasaran TBS kelapa sawit berjalan, dan mengetahui margin pemasaran petani dalam rantai pemasaran TBS kelapa sawit di Desa Jonggon, Kabupaten Kutai Kartanegara. Penelitian ini diharapkan dapat memberikan manfaat bagi pemerintah, sebagai bahan masukan dalam membuat kebijakan dalam menentukan harga TBS, dengan mempertimbangkan berbagai aspek termasuk aspek penjualan TBS kelapa sawit. Penelitian ini juga diharapkan dapat memberikan manfaat bagi masyarakat khususnya yang mendalami bidang perkebunan kelapa sawit diharapkan dapat menambah khazanah ilmu pengetahuan mengenai rantai pemasaran TBS. Bagi masyarakat yang khususnya mendalami bidang ilmu pengetahuan, riset, dan penelitian, penelitian ini dapat menjadi bahan untuk melakukan kegiatan penelitian selanjutnya sehingga diharapkan dapat bermanfaat bagi kemajuan bidang ilmu pengetahuan, riset, dan penelitian.

\section{METODOLOGI}

\section{Tempat dan Waktu}

Penelitian ini dilaksanakan di PT. Niaga Mas Gemilang (NMG), kemudian dilanjutkan di Desa Jonggon yang terletak di Kabupaten Kutai Kartanegara, pada bulan Juli hingga Agustus 2020.

\section{Alat dan Bahan}

Alat dan bahan yang digunakan dalam penelitian ini sebagai bahan penelitian adalah wawancara dengan narasumber yang telah ditentukan menggunakan kuesioner yang telah ditentukan sebelumnya, selama wawancara digunakanlah alat perekam suara berupa handphone.

\section{Populasi dan Sampel}

Populasi dari penelitian ini adalah pekerja di pabrik PT. SKJ. Sedangkan sampel dari penelitian ini adalah semua pekerja Departemen Proses di pabrik PT. SKJ.

\section{Prosedur Kerja}

Dalam penelitian ini pengambilan sampel menggunakan teknik Purposive Sampling yakni teknik pengambilan sampel sumber data dengan pertimbangan tertentu, misalnya orang tersebut dianggap paling tahu tentang apa yang penulis harapkan (Sugiyono, 2009).

Data yang digunakan dalam penelitian ini adalah data sekunder dan data primer. Data sekunder berupa data harga TBS yang ditetapkan oleh pemerintah pada bulan Agustus 2020. Data primer diperoleh dari petani nonplasma, pedagang, petani plasma, dan koperasi berupa harga jual, harga beli, informasi harga dan data yang berhubungan dengan Rantai Pemasaran TBS ke pabrik pengolahan milik perusahaan yang ada di Desa Jonggon Kabupaten Kutai Kartanegara.

\section{Analisis Data}

\section{a. Analisis Deskriptif}

Metode analisis dalam pengolahan data yang digunakan untuk mengetahui aliran rantai Pemasaran di Desa Jonggon adalah analisis deskriptif. Data yang diperoleh dianalisis dengan cara dideskripsikan sesuai dengan data yang telah terkumpul dan keadaan di lapangan. Menurut Sugiyono (2008), analisis deskriptif merupakan analisis yang bertujuan untuk menjabarkan suatu fenomena yang terjadi saat ini dengan menggunakan prosedur ilmiah untuk menjawab masalah secara aktual.

Analisis deskriptif dalam penelitian ini digunakan untuk menjelaskan secara menyeluruh (komprehensif) tentang data dan informasi yang diperoleh dari lapangan.

b. Margin Pemasaran 
Berdasarkan tinjauan pustaka menurut Limbong dan Sitorus (1978) margin pemasaran dapat dihitung dengan menggunakan rumus:

$$
\mathrm{MP}=\mathrm{Hp}-\mathrm{Hb}
$$

MP : Margin pemasaran (rupiah/kg).

$\mathrm{Hb}$ : Harga beli (rupiah/kg).

Hp : Harga penjualan (rupiah/kg).

Sementara besarnya bagian yang diterima petani (Farmer's Share = FS) diestimasi dengan menggunakan rumus sebagai berikut:

$$
\mathrm{FS}=\frac{\mathrm{HP}}{\mathrm{HK}} \times 100 \%
$$

HP : Harga di tingkat petani (rupiah $/ \mathrm{kg}$ ).

HK : Harga di tingkat perusahaan (rupiah/kg).

\section{HASIL DAN PEMBAHASAN}

\section{Gambaran Umum Desa Jonggon}

Desa Jonggon berada di

Kecamatan Loa Kulu, Kabupataen Kutai Kartanegara, Provinsi Kalimantan Timur. Desa Jonggon memiliki luas wilayah 3.000 ha, secara geografis berada pada ketinggian $\pm 300 \mathrm{~m}$ di atas permukaan laut, dengan keadaan topografi tanah adalah dataran tinggi. Desa Jonggon berjarak 30 $\mathrm{km}$ dari Pusat Pemerintahan Kabupaten Kutai Kartanegara dan 60 km dari lbukota Provinsi. Penduduk Desa Jonggon merupakan transmigran dari Pulau Jawa yang banyak bekerja sebagai petani dengan modal lahan yang diberikan oleh pemerintah, yakni tanah dengan luas 1,25 ha sampai 1,60 ha. Berbagai sektor usaha yang ditekuni penduduk Desa Jonggon antara lain toko sembako, perbengkelan, pertukangan dan berbagai sektor lainnya. Hal ini membuat kondisi ekonomi Desa Jonggon dinamis.

\section{Lembaga Perusahaan}

Pihak-pihak dalam Rantai Pemasaran TBS di Desa Jonggon meliputi: petani nonplasma, pedagang, petani plasma dan KSU-SMS. Karakteristik pihak-pihak tersebut adalah sebagai berikut : a. Petani Nonplasma

Petani nonplasma adalah petani yang tidak memiliki keterikatan dengan perusahaan. Petani nonplasma sebagai salah satu penghasil TBS dalam Rantai Pemasaran TBS yang ada di Desa Jonggon. Petani nonplasma dalam menjual TBS ke PT. NMG seluruhnya melalui lembaga pemasaran. Lembaga pemasaran yang terkait dalam Rantai Pemasaran TBS yaitu pedagang. Lembaga pemasaran tersebut berfungsi sebagai pedagang pengumpul perantara petani dalam menjual TBS ke pabrik pengolahan.

Tabel 1. Karakteristik Petani Nonplasma di Desa Jonggon

\begin{tabular}{cll}
\hline No & Uraian & Persentase \\
\hline \multirow{4}{*}{1} & Umur & \\
& $20-29$ & $35 \%$ \\
& $30-39$ & $15 \%$ \\
& $40-49$ & $45 \%$ \\
& $50-59$ & $5 \%$ \\
\hline \multirow{2}{*}{2} & Luas Lahan & \\
& 1.0 ha. -1.5 ha. & $70 \%$ \\
& 1.6 ha. -2.0 ha. & $30 \%$ \\
\hline
\end{tabular}

Menurut Depkes RI (2009) usia produktif adalah usia antara 15 tahun sampai dengan 54 tahun. Petani yang berada pada umur produktif akan memberikan hasil kerja yang maksimal jika dibandingkan dengan umur yang tidak produktif karena pada umur produktif umumnya seseorang memiliki kemampuan yang lebih baik dalam berfikir dan bertindak untuk melakukan kegiatan (Sari, 2011). Jumlah petani nonplasma yang menjadi responden dalam penelitian ini adalah 20 orang. Total tanaman kelapa sawit milik petani nonplasma berumur 4 sampai 5 tahun sebab penanaman sawit menunggu petani memiliki dana untuk melakukan penanaman mandiri, oleh sebab itu umur tanaman kelapa sawit milik petani nonplasma relatif lebih muda daripada petani plasma. 
Tabel 2. Produktivitas Lahan Petani Nonplasma di Desa Jonggon

\begin{tabular}{|c|c|c|c|c|}
\hline NO & $\begin{array}{c}\text { LUAS } \\
\text { LAHA } \\
\mathbf{N}\end{array}$ & $\begin{array}{c}\text { JUMLAH } \\
\text { LUAS } \\
\text { LAHAN }\end{array}$ & $\begin{array}{c}\text { RATA }^{2} \\
\text { PRODUKSI }\end{array}$ & $\begin{array}{c}\text { RATA }^{2} \\
\text { PRODUKT } \\
\text { IVITAS }\end{array}$ \\
\hline 1 & $\begin{array}{l}1.0 \\
1.5\end{array}$ & 17.50 ha & 0.99 ton & 0.79 ton/ha \\
\hline 2 & $\begin{array}{l}1.6 \\
2.0\end{array}$ & 9.60 ha & 1.25 ton & 0.78 ton/ha \\
\hline
\end{tabular}

Hasil penelitian menunjukkan bahwa petani nonplasma dengan luas lahan kurang dari 1,5 ha dengan jumlah luas lahan 17.50 ha memiliki rata-rata produksinya 0.99 ton, lebih kecil daripada petani nonplasma yang memiliki luas lahan lebih dari 1,5 ha dengan jumlah luas lahan yang lebih kecil, yakni 9.60 ha dengan rata-rata produksinya sebesar 1.25 ton. Hal ini berbeda dengan yang dikemukakan oleh Deswita dkk. (2011), bahwa jumlah produksi sawit juga dipengaruhi oleh luas lahan yang dimiliki. Semakin luas lahan perkebunan yang diusahakan ( $\geq 1,5 \mathrm{ha}$ ), semakin besar pula hasilnya dan sebaliknya semakin kecil lahan perkebunan yang diusahakan $(\leq 1,5$ ha), semakin kecil pula hasilnya.

\section{b. Petani Plasma}

Petani plasma merupakan petani yang memiliki keterikatan atau kontrak dengan perusahaan. Petani plasma yang berada di Desa Jonggon masih memiliki pengalaman relatif minim yaitu 8 tahun. Hal ini terjadi karena petani baru mulai berusahatani setelah Koperasi Sawit Mekar Sari didirikan (2012). TBS yang dihasilkan oleh petani plasma langsung dikirim ke pabrik pengolahan milik PT. NMG tanpa melalui pedagang pengumpul perantara atau koperasi karena penjualan TBS ke pabrik pengolahan milik PT. NMG adalah sebuah kewajiban yang harus dilakukan petani yang menjadi anggota plasma. Tabel 3 menunjukkan karakteristik petani plasma yang berperan dalam kegiatan Rantai Pemasaran TBS di PT. NMG.
Tabel 3. Karakteristik Petani Plasma di Desa Jonggon

\begin{tabular}{lll}
\hline No & Uraian & Persentase \\
\hline & Umur & \\
& $20-29$ & $17,1 \%$ \\
1 & $30-39$ & $14,2 \%$ \\
& $40-49$ & $60,0 \%$ \\
& $50-59$ & $8,5 \%$ \\
\hline \multirow{3}{*}{2} & Luas Lahan \\
& $1.0-1.5$ ha & $65.7 \%$ \\
& $1.6-2.0$ ha & $34.3 \%$ \\
\hline
\end{tabular}

Menurut Depkes RI (2009) usia produktif adalah usia antara 15 tahun sampai dengan 54 tahun. Petani yang berada pada umur produktif akan memberikan hasil kerja yang maksimal jika dibandingkan dengan umur yang tidak produktif karena pada umur produktif umumnya seseorang memiliki kemampuan yang lebih baik dalam berfikir dan bertindak untuk melakukan kegiatan (Sari, 2011). Jumlah petani plasma yang menjadi responden dalam penelitian ini adalah 35 orang. Umur tanaman kelapa sawit milik petani plasma lebih tua sebab penanaman dilakukan bersamaan dengan berdirinya koperasi dan pabrik pengolahan milik PT. NMG.

Tabel 4. Produktivitas Lahan Petani Plasma di Desa Jonggon

\begin{tabular}{|c|c|c|c|c|}
\hline NO & $\begin{array}{l}\text { LUAS } \\
\text { LAHAN }\end{array}$ & $\begin{array}{c}\text { JUMLAH } \\
\text { LUAS LAHAN }\end{array}$ & $\begin{array}{c}\text { RATA }^{2} \\
\text { PRODUKSI }\end{array}$ & $\begin{array}{c}\text { RATA }^{2} \\
\text { PRODUKTI } \\
\text { VITAS }\end{array}$ \\
\hline 1 & $\begin{array}{l}1.0 \\
1.5\end{array}$ & 28.75 ha. & 1.45 ton & $\begin{array}{l}1.16 \\
\text { ton/ha. }\end{array}$ \\
\hline 2 & $\begin{array}{l}1.6 \\
2.0\end{array}$ & 20.10 ha. & 1.94 ton & $\begin{array}{l}1.16 \\
\text { ton/ha. }\end{array}$ \\
\hline
\end{tabular}

Hasil penelitian menunjukkan bahwa petani plasma dengan luas lahan kurang dari 1,5 ha dengan jumlah luas lahan 28.75 ha memiliki rata-rata produksinya 1.45 ton, lebih kecil daripada petani nonplasma yang memiliki luas lahan lebih dari 1,5 ha dengan jumlah luas lahan 20.10 ha dengan rata-rata produksinya sebesar 1.94 ton. Hal ini berbeda dengan yang dikemukakan oleh Deswita dkk. (2011), bahwa jumlah produksi sawit juga dipengaruhi oleh luas lahan yang dimiliki. Semakin luas lahan 
perkebunan yang diusahakan ( $\geq 1,5$ ha), semakin besar pula hasilnya dan sebaliknya semakin kecil lahan perkebunan yang diusahakan ( $\leq 1,5 \mathrm{ha})$, semakin kecil pula hasilnya.

\section{c. Pedagang}

Pedagang pengumpul yaitu pedagang pengumpul perantara yang menjual TBS kepada perusahaan. Modal yang digunakan dalam usahanya adalah modal sendiri. Setiap hari pedagang pengumpul membeli TBS langsung dari petani dan kemudian menjualnya ke pabrik pengolahan. Petani menjual TBS yang telah dipanen tanpa ada ikatan antara keduanya. Namun ada juga petani yang menjual TBS ke pedagang pengumpul karena terikat pinjaman dengan pedagang, sehingga untuk melunasi pinjaman tersebut TBS dijual kepada yang bersangkutan.

\section{d. Koperasi Serba Usaha Sawit Mekar} Sari (KSU-SMS)

Koperasi Sawit Mekar Sari merupakan koperasi serba usaha yang berperan sebagai plasma dalam Pemasaranan TBS di PT. NMG. Koperasi Sawit Mekar Sari berada di Desa Jonggon RT : 002 Kecamatan Loa Kulu Kabupaten Kutai Kartanegara. Adanya KSU-SMS dapat membantu petani plasma dalam menjual TBS ke pabrik pengolahan. KSUSMS telah memiliki Badan Hukum No, 199/BH/XX.5/VII/2012. KSU-SMS berdiri pada tahun 2012 yang diketuai oleh Bapak Jamran. Jumlah anggota koperasi itu sendiri sudah 35 orang dan diperkirakan akan terus meningkat. Tujuan didirikannya Koperasi Serba Usaha Sawit Mekar Sari (KSU-SMS) adalah untuk :

a. Meningkatkan kesejahteraan dan taraf hidup anggota pada khususnya dan daerah kerja pada umumnya.

b. Menjadi gerakan ekonomi rakyat serta ikut membangun tatanan perekonomian nasional.
PT. Niaga Mas Gemilang (PT. NMG) adalah perusahaan tempat pabrik pengolahan TBS berada, Dari hasil wawancara dengan Kepala bagian Pengembangan Sumberdaya Manusia (HRD) perusahaan tersebut memiliki pabrik pengolahan dengan kapasitas terpasang sebesar 60 ton TBS/jam dan jumlah TBS yang dibutuhkan oleh PT. NMG dalam sehari sebesar 1440 ton, namun kenyataanya kebun inti belum mampu menghasilkan produksi sebesar itu dalam sehari, dalam hal ini hasil produksi TBS di kebun inti hanya mampu mencukupi $40 \%$ dari kapasitas produksi pabrik yang dimiliki, PT. NMG belum mampu memenuhi kapasitas produksi karena kekurangan bahan baku.

PT NMG membutuhkan

Pemasaranan tambahan bahan baku dari luar sekitar 60\% untuk mencukupi kapasitas pabrik pengolahan yang dibutuhkan, untuk menutupi kekurangan bahan baku tersebut perusahaan memasok bahan baku TBS dari luar perusahaan yakni dari kebun plasma dan masyarakat luar. Pemasokan bahan baku dari luar perusahaan (plasma dan nonplasma) akan dapat menjamin Pemasaranan bahan baku ke pabrik pengolahan menjadi lancar untuk memenuhi kapasitas mesin yang dimiliki perusahaan.

\section{Manajemen Rantai Pemasaran}

Hasil penelitian menunjukkan bahwa terdapat 2 pola aliran Rantai Pemasaran TBS di Desa Jonggon, yaitu: Pola aliran rantai Pemasaran I, Pola aliran rantai Pemasaran II, seperti terlihat pada Gambar 2.



Gambar 1. Pola Rantai Pemasaran TBS di Desa Jonggon d. Pabrik Pengolahan PT. Niaga Mas Gemilang a. Pola Rantai Pemasaran

1) Rantai Pemasaran 1 


\section{PETANI

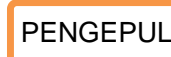 \\ $\Rightarrow$ \\ PABRIK}

Gambar 2. Pola Aliran 1 Rantai Pemasaran TBS

2) Rantai Pemasaran 2

PETANI KOPERASI
PABRIK
PENGOLAHAN

\section{Gambar 3. Pola Aliran 2 Rantai Pemasaran TBS}

Pada pola aliran rantai Pemasaran 2 merupakan aliran TBS dari petani plasma ke koperasi kemudian ke pabrik pengolahan PT. NMG seperti terlihat pada Gambar 4.

b. Manajemen Rantai Pemasaran

1) Aliran Produk

\section{Rantai Pemasaran 1}

Setelah TBS tersusun di TPH, TBS dimuat diatas truk pedagang, kemudian langsung dibawa ke Pabrik pengolahan. Jarak antara kebun petani nonplasma dan pabrik pengolahan sekitar $25 \mathrm{~km}$ dan biasa ditempuh dalam waktu 25 sampai 30 menit, bila cuaca dan kondisi jalan licin 40 sampai 60 menit tergantung kondisi dan cuaca di jalan.

Hal ini berbeda dengan penelitian yang dilakukan oleh Primalasari dkk. (2016) dimana TBS yang telah dipanen oleh petani nonplasma dijual ke lembaga pemasaran yaitu pedagang pengumpul dan/atau supplier sebelum kemudian

\section{Rantai Pemasaran 2}

Setelah tersusun dengan rapi di TPH selanjutnya TBS langsung dibawa ke Pabrik pengolahan. Jarak antara kebun petani plasma dan pabrik pengolahan sekitar $10 \mathrm{~km}$ dan biasa ditempuh dalam waktu 10 sampai 15 menit, apabila cuaca dan kondisi jalan licin dapat ditempuh sekitar 25 sampai 30 menit tergantung kondisi dan cuaca di jalan.

2) Aliran keuangan

\begin{tabular}{|c|c|}
\hline Rantai Pemasaran 1 & Rantai Pemasaran 2 \\
\hline $\begin{array}{l}\text { Aliran keuangan berasal dari PT. NMG } \\
\text { kemudian ke pedagang pengumpul dan } \\
\text { petani nonplasma. TBS dibayar oleh } \\
\text { pihak perusahaan kepada pedagang } \\
\text { pengumpul melalui transfer lewat } \\
\text { rekening bank yang telah disepakati } \\
\text { dalam tempo } 7 \text { hari setelah TBS } \\
\text { diangkut ke pabrik pengolahan. } \\
\text { Kemudian pembayaran antara } \\
\text { pedagang pengumpul dengan petani } \\
\text { yaitu secara cash atau tunai di hari } \\
\text { yang sama setelah TBS ditimbang, } \\
\text { menggunakan uang pribadi pedagang, } \\
\text { pembayaran berdasarkan jumlah berat } \\
\text { TBS pada saat dilakukan penimbangan } \\
\text { di pabrik pengolahan. }\end{array}$ & $\begin{array}{l}\text { Aliran keuangan pada rantai Pemasaran } 2 \\
\text { berasal dari PT. NMG kepada Koperasi dan } \\
\text { kemudian ke Petani Plasma. Akumulasi } \\
\text { TBS yang terkirim selama } 3 \text { bulan akan } \\
\text { dibayar oleh pihak perusahaan melalui } \\
\text { rekening bank yang telah disepakati. Petani } \\
\text { dapat menerima uang pembayaran dengan } \\
\text { ditransfer oleh koperasi dengan dikurangi } \\
\text { biaya pemasaran yang ada. }\end{array}$ \\
\hline
\end{tabular}

TBS dijual ke Pabrik Pengolahan. Sedangkan pada petani plasma terjadi hal yang sama dimana TBS yang telah dipanen kemudian wajib dijual kepada koperasi, sebelum kemudian TBS dijual ke pabrik pengolahan.
Pada rantai pemasaran 1 petani dan pedagang pengumpul aliran finansial sesuai dengan penelitian Primalasari dkk. (2016) dimana petani 
langsung memperoleh uang dari hasil penjualan TBS tanpa menunggu terlalu lama, proses pembayaran yang terjadi cepat dan mudah, akan tetapi berbeda dengan rantai pemasaran 2 pada penelitian Primalasari dkk. (2016) perusahaan membayarkan hasil penjualan TBS kepada petani plasma lewat koperasi secara tunai saat proses jual beli TBS, selain itu petani langsung memperoleh uang dari hasil penjualan TBS lebih cepat yakni dalm waktu 3 hari.

3) Aliran Informasi

\begin{tabular}{|c|c|}
\hline Rantai Pemasaran 1 & Rantai Pemasaran 2 \\
\hline $\begin{array}{l}\text { Informasi dari Perusahaan ke } \\
\text { Pedagang pengumpul adalah } \\
\text { informasi perubahan harga TBS dan } \\
\text { kriteria panen Perusahaan, dan } \\
\text { informasi dari Pedagang pengumpul ke } \\
\text { Petani adalah informasi mengenai } \\
\text { bagaimana kriteria panen yang baik. } \\
\text { Pertukaran informasi antara Pedagang } \\
\text { pengumpul dan Perusahaan biasanya } \\
\text { dilakukan lewat Telepon, dan antara } \\
\text { Pedagang pengumpul dan Petani } \\
\text { adalah saat bertemu langsung. }\end{array}$ & $\begin{array}{l}\text { Informasi dari Perusahaan berupa } \\
\text { informasi perubahan harga, dan kriteria } \\
\text { panen TBS Perusahaan kepada pihak } \\
\text { Koperasi, informasi itu juga disampaikan } \\
\text { kepada Petani Plasma. Pertukaran } \\
\text { informasi antara Koperasi dan Perusahaan } \\
\text { biasanya dilakukan lewat sambungan } \\
\text { telepon, dan antara Koperasi dan Petani } \\
\text { lewat pertemuan rutin. }\end{array}$ \\
\hline
\end{tabular}

Hal ini sesuai dengan penelitian Primalasari dkk. (2016) dimana arus informasi berasal dari perusahaan ke pedagang pengumpul dan dari perusahaan ke koperasi kemudian ke petani plasma, mengenai perubahan harga TBS dan jumlah TBS.
Perusahaan memberikan informasi berupa perubahan harga kepada koperasi kemudian informasi diberikan kepada petani, akan tetapi tidak semua informasi yang dimiliki oleh pedagang pengumpul diberikan kepada petani nonplasma.

4) Insentif

\begin{tabular}{|c|c|}
\hline Rantai Pemasaran 1 & Rantai Pemasaran 2 \\
\hline $\begin{array}{l}\text { Petani } \text { mendapatkan } \\
\text { keuntungan berupa pinjaman dana } \\
\text { dan keringanan pembayaran atau } \\
\text { cicilan dari pedagang. Biaya ini } \\
\text { biasanya digunakan sebagai biaya } \\
\text { untuk membeli pupuk dan untuk } \\
\text { membiayai Pendidikan anggota } \\
\text { keluarga yang masih dalam jenjang } \\
\text { pendidikan. }\end{array}$ & $\begin{array}{l}\text { Petani plasma mendapat keuntungan } \\
\text { berupa jaminan harga yang tidak mudah } \\
\text { berubah-ubah sebab petani mendapatkan } \\
\text { kepastian harga berdasarkan ketetapan } \\
\text { pemerintah, selain itu petani plasma } \\
\text { mendapatkan bantuan pupuk dan bahan } \\
\text { kimia untuk mengendalikan gulma, hama, } \\
\text { dan penyakit dalam menjalankan usaha } \\
\text { perkebunan, serta petani plasma mendapat } \\
\text { dana sisa hasil usaha (SHU) dari kegiatan } \\
\text { jual beli seperti transportasi dan bahan bakar }\end{array}$ \\
\hline
\end{tabular}

Pada rantai pemasaran 2 petani mendapatkan berbagai manfaat salah satunya adalah petani plasma pada setiap akhir tahun menerima dana SHU dari hasil yang didapat dari kegiatan jual beli TBS seperti pendapatan dari sarana transportasi dan biaya bahan bakar. Hal ini sesuai dengan penelitian Tambunan (2017) dimana koperasi dapat memberikan insentif bagi petani plasma. Selain itu pada rantai pemasaran 1 biaya yang dipinjam oleh petani juga sesuai dengan penelitian Tambunan (2017) dimana petani memerlukan 
pendanaan untuk biaya pembelian

pupuk.

5) Koordinasi

\begin{tabular}{|c|c|}
\hline Rantai Pemasaran 1 & Rantai Pemasaran 2 \\
\hline $\begin{array}{l}\text { Petani sawit non-plasma dan } \\
\text { pedagang pengumpul dalam } \\
\text { menjalankan usahanya saling tidak } \\
\text { berkoordinasi mengenai jalannya } \\
\text { pemasaran TBS ke pabrik } \\
\text { pengolahan, sehingga pedagang } \\
\text { pengumpul plasma mutlak memiliki } \\
\text { kontrol jalannya pemasaran TBS, dan } \\
\text { bertanggung jawab atas TBS karena } \\
\text { petani nonplasma akan memberikan } \\
\text { biaya pemasaran TBS kepada } \\
\text { pedagang. }\end{array}$ & $\begin{array}{l}\text { Petani plasma dan koperasi dalam } \\
\text { menjalankan } \text { usahanya saling } \\
\text { berkoordinasi mengenai jalannya } \\
\text { pemasaran TBS ke pabrik pengolahan. } \\
\text { Koperasi memiliki kuasa untuk mengontrol } \\
\text { jalannya pemasaran TBS sebab koperasi } \\
\text { bertanggung jawab atas TBS karena petani } \\
\text { plasma memberikan biaya pemasaran TBS } \\
\text { kepada koperasi sesuai dengan kontrak } \\
\text { atau perjanjian yang telah ditetapkan } \\
\text { keduanya. }\end{array}$ \\
\hline
\end{tabular}

Petani di kedua rantai Pemasaran memiliki alasan yang sama dalam berkoordinasi dengan pihak kedua (Pedagang pengumpul dan Koperasi) yaitu sama-sama tidak memiliki kendaraan angkut TBS milik sendiri, sehingga biaya pemasaran dibebankan kepada pihak kedua, hal ini sesuai dengan penelitian yang dilakukan oleh Primalasari dkk. (2016) bahwa petani memilih untuk menjual perusahaan. Margin pemasaran terdiri dari biaya pemasaran dan keuntungan pemasaran yang diperoleh dari harga jual dikurangi dengan harga beli dari setiap lembaga yang terlibat.

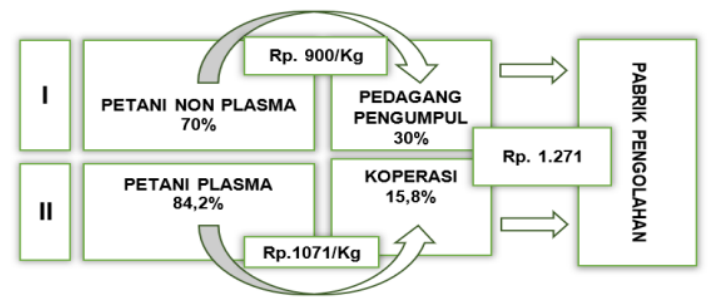

Gambar 5. Keuntungan Pemasaran Pelaku Usaha Rantai Pemasaran TBS

Pada Gambar. 5 dapat diamati
bahwa dalam rantai Pemasaran,
keuntungan yang diterima oleh pedagang
pengumpul lebih besar persentasenya
daripada yang diterima koperasi. Akan
tetapi rantai Pemasaran 1 tidak lebih baik
TBS melalui pihak kedua disebabkan oleh keterbatasan sarana pengangkutan berupa kendaraan pengangkut TBS.

\begin{abstract}
Margin Pemasaran
Margin pemasaran merupakan selisih harga yang diterima oleh masing masing lembaga pemasaran, sedangkan Farmer's Share merupakan bagian yang diterima petani dari harga di tingkat dalam memberikan keuntungan kepada petani sebab keuntungan petani plasma pada rantai Pemasaran 2 lebih besar dengan selisih Rp.171/Kg. Hal ini sesuai dengan penelitian Primalasari dkk. (2016) dimana pedagang pengumpul memiliki persentase farmers share yang lebih besar dari koperasi, hanya saja dalam penelitian tersebut terdapat 4 pola aliran rantai Pemasaran dan 6 lembaga pemasaran.
\end{abstract}

\section{KESIMPULAN}

1. Terdapat lima pelaku aliran rantai pemasaran TBS di Desa Jonggon yaitu:
a. Petani Nonplasma
b. Petani Plasma
c. Pedagang Pengumpul
d. Koperasi "KSU-SMS"
e. Pabrik Pengolahan PT. NMG 
2. Terdapat dua pola aliran rantai pemasaran TBS di Desa Jonggon yaitu:

a. Pola aliran rantai pemasaran 1: Petani Nonplasma - Pedagang pengumpul -- Pabrik Pengolahan PT. NMG

b. Pola aliran rantai pemasaran 2 :

Petani Plasma - Koperasi SMS Pabrik Pengolahan PT. NMG

3. Petani plasma menerima share sebesar Rp. 900/kg dan petani nonplasma menerima Rp. 1070/kg.

\section{DAFTAR PUSTAKA}

Asmarantaka, R. W. 2012. Pemasaran Agribisnis (Agrimarketing). Departemen Agribisnis. Fakultas Ekonomi dan Manajemen. Bogor: Institut Pertanian Bogor.
Asngari, I. Analisis Taraf Hidup Petani Skala Kecil di Sumatera Selatan. Fakultas Ekonomi. Palembang: Universitas Sriwijaya.

Basu, Swastha. 2001. Manajemen Penjualan, Cetakan Kelima. Yogyakarta: Penerbit BPSE.

Bisuk Putra. 2009. Analisis Saluran Pemasaran Kelapa Sawit di Desa Mananti Kecamatan Sosa Kabupaten Padang Lawas Provinsi Sumatera Utara. Fakultas Pertanian. Bogor: Institut Pertanian Bogor. 